\title{
Impact of plot maintenance and level of cocoa tree leaf cover on spread of Swollen shoot disease in Côte d'Ivoire: Case of Petit-Bondoukou site
}

\author{
Franck Zokou Oro ${ }^{1, *}$, Hermann-Desiré Lallie ${ }^{2}$, Kouassi Guy Brou ${ }^{1}$, Juslin \\ Kouadio Koigny ${ }^{1}$ and Hortense Atta Diallo ${ }^{3}$
}

\begin{abstract}
${ }^{1}$ Department of de Plant Biology, Faculty of Biological Sciences, Peleforo GON COULIBALY University, Korhogo, Côte d'Ivoire ${ }^{2}$ Department of Genetics-Biochemistry, Faculty of Biological Sciences, Peleforo GON COULIBALY University, Korhogo, Côte d'Ivoire ${ }^{3}$ Phytopathology Research Unit, Department of Plant and Environmental Protection, Nangui Abrogoua University, Abidjan, Côte d'Ivoire *Corresponding author
\end{abstract}

\begin{abstract}
Swollen shoot is a viral disease of cocoa that is developing in the region of Soubré and is causing very serious damage. However, little is known about the epidemiological factors responsible for this disease, which makes it difficult to control the swollen shoot virus. The main objective of this study was to determine the influence of plot maintenance level and the leaf cover of tree on the prevalence of Swollen shoot disease at the site of Petit-Bondoukou. The observation system consists of a sentinel size $10 \mathrm{~km} \mathrm{X10} \mathrm{km.} \mathrm{Each} \mathrm{sentinel}$ site is made up of 16 clusters of $2.5 \mathrm{~km} \mathrm{X} 2.5 \mathrm{~km}$ containing about 10 plots which constitute the different observation points. In this study, observations were made in 4 plots of the site. The variables measured during data collection were the number of trees affected by the swollen shoot, the leaf cover level of each test tree and the maintenance level of sampling plots. A descriptive analysis was carried out with the data in order to understand their dispersal. Comparative analysis of swollen shoot prevalence and leaf cover level using the one-way ANOVA showed a significant relationship. Comparison of swollen shoot prevalence and plot maintenance level using the Kruskall-Wallis test showed that the prevalence of swollen shoot disease did not depend on the maintenance level. However, the leaf cover level of the test trees influenced the prevalence of swollen shoot disease. This is justified by the fact that test trees with low or medium leaf cover had significantly higher prevalences of CSSV.
\end{abstract}

Keywords-Cocoa tree, Côte d'Ivoire, CSSV, leaf cover, maintenance level, Soubré.

\section{INTRODUCTON}

Cocoa farming is of great importance in the Ivorian economy, accounting for $40 \%$ of export earnings and contributing $15 \%$ of gross domestic product (GDP) (Tano, 2012) with an annual production of more than 1.5 million tons (Serges, 2014). Despite the socio-economic performance of cocoa production in Côte d'Ivoire, numerous constraints related to diseases and pests threaten the sustainability of cocoa production (Freud et al., 2000). These constraints lead to declining production and increasing poverty in rural areas (Koua et al., 2018). In Côte d'Ivoire, black pod disease and swollen shoot disease are the two main diseases that pose a major threat to cocoa production (Kouakou et al., 2011). Cocoa Swollen Shoot Disease (CSSD) is a viral disease transmitted by mealybugs of the Pseudococcidae family (Dzahini-Obiatey et al., 2010;
N'guessan et al., 2019). The pathogen of swollen shoot disease is called Cocoa Swollen Shoot Virus (CSSV) and belongs to the genre of Badnavirus (Hagen et al., 1993; Muller and Sackey, 2005).This disease typically manifests by redness on young leaves (Fig. 1) and swelling of stems (Oro et al., 2012). Physiologically, the trees affected by swollen shoot disease gradually lose their leaves until their death in the fifth year of infection (Partiot et al., 1978). This also leads to stunted pods and therefore a significant drop in yield (Kouakou et al., 2011). Since discovery of this disease, it has remained localized for a long time in the east of Côte d'Ivoire (Alibert, 1946; Kébé, 2005). It was only in 2003 that new outbreaks were discovered in west-central Côte d'Ivoire, notably in Sinfra, Issia and Bouaflé departments (Kébé and N'guessan, 2003). In these new outbreaks, new more virulent species have been identified (Koffié et al., 
2012). These new species could be responsible of the rapid spread of the CSSD in all the cocoa production areas in Côte d'Ivoire. In addition, certain factors linked to cultural practices, including plot maintenance and the rate of leaf cover, could accentuate the spread of the virus, as already observed in the case of black pod disease (Oro et al., 2019).

Since discovery of swollen shoot disease outbreak in Côte d'Ivoire, no studies have been carried out to identify the major factors influencing the development of this disease (Diby et al., 2014). In addition to this, there is no basis for

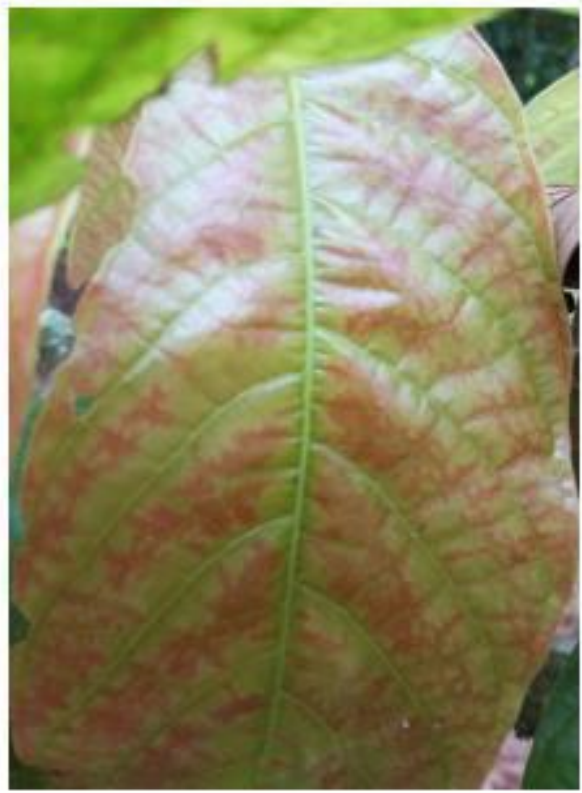

an information system on the prevalence of the disease that can inform decision-makers and research structures to develop effective methods of control (Diby et al., 2014). This is therefore what motivates this study, so the main objective is to assess the impact of maintenance factors and the level of coverage of plots on the prevalence of CSSV. In other words, the aim is to study the relationship between the prevalence of swollen shoot disease and the two factors of the maintenance level and the leaf cover level of the plots in order to develop a farming control methods.

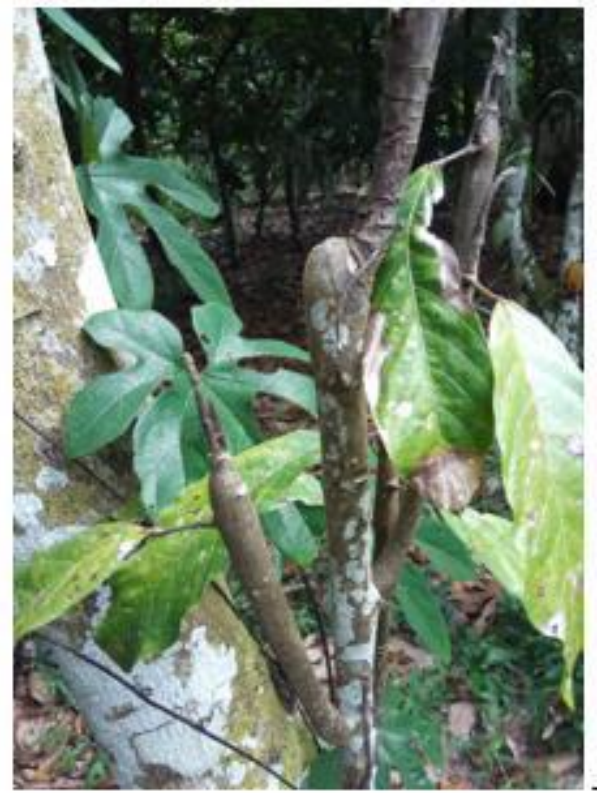

Fig.1: Some symptoms to detect Swollen Shoot Virus disease in the farm. (A): Redness along the veins of young cocoa leaves followed by discoloration between the veins; (B): Stem swelling (Photo taken by Oro)

\section{MATERIAL AND METHODS}

\subsection{Study Site}

This study was conducted in Petit-Bondoukou in the Department of Soubré (region of Nawa). The region of Nawa is a forested area whose vegetation is essentially dominated by dense forest with deep, permeable and welldrained soil that is suitable for all types of crops, particularly cocoa. The region of Nawa constitutes the first cocoa production area in Côte d'Ivoire with a production that is close to $20 \%$ of the national production (Tano, 2012). The climate of the region of Nawa is equatorial type locally called "Attieen climate" (N'Guettia, 2015). This climate is characterized by heavy rainfall which varies depending on the year. This rainfall varies between $1400 \mathrm{~mm}$ and 1600 $\mathrm{mm}$. Atmospheric humidity is high $(90 \%)$ with a low annual variation of thermal amplitude $\left(28^{\circ} \mathrm{C}\right)$ and an alternation of a long rainy season and a short dry season (N'Guettia, 2015). This region is highly threatened by swollen shoot disease, which is why it was chosen for this area (Fig. 2). 

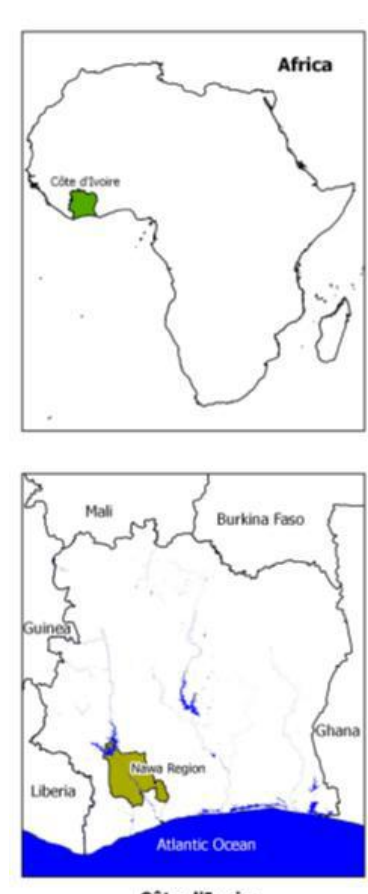

Côte d'Ivoire

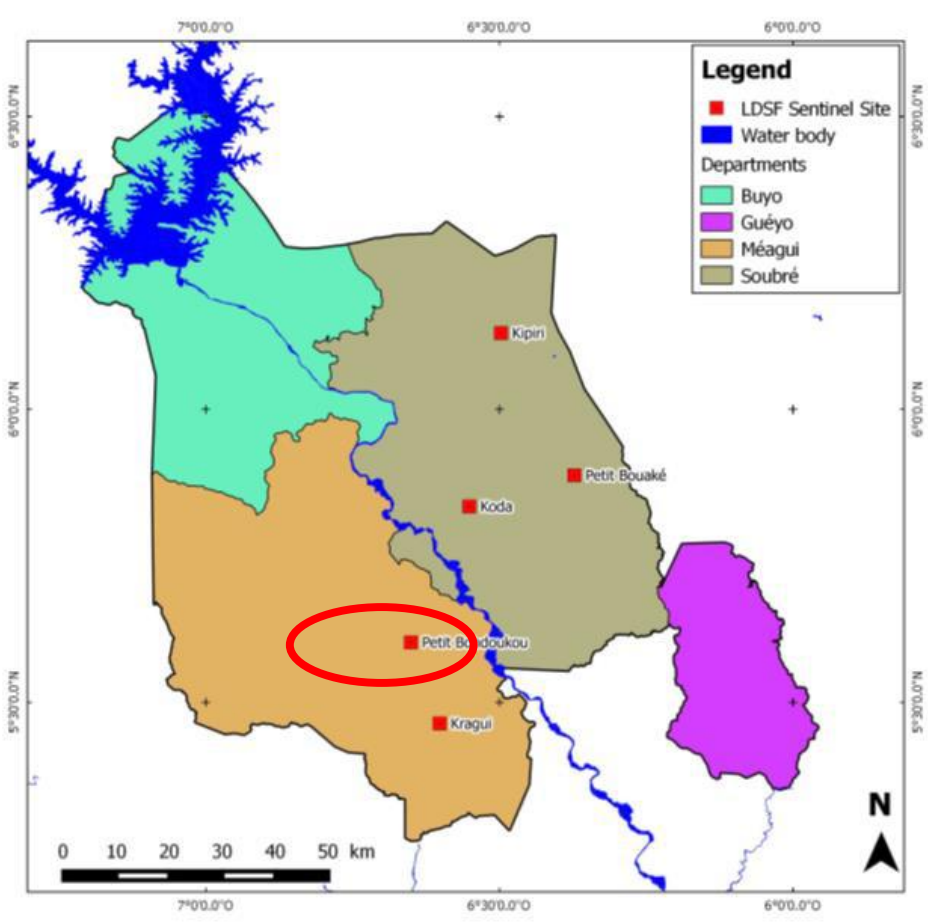

Fig.2: Map of the study area highlighting Petit-Bondoukou site (Diby et al., 2014)

\subsection{Experimental device}

The experimentation took place in peasant cocoa plots based on prospecting surveys. The surveys were conducted according to the Land Degradation Surveillance Framework (LDSF) which was developed to monitor soil quality in West Africa (Diby et al., 2014). This device was adapted in the framework of this study to collect epidemiological data on swollen shoot disease in cocoa trees (Diby et al., 2014). The LDSF represents a sentinel site of $10 \mathrm{~km} \times 10 \mathrm{~km}$, subdivided into 16 clusters of 2.5 $\mathrm{km} \times 2.5 \mathrm{~km}$ (Fig. 3). Each cluster comprises more than 10 observation points, known as plots. Around each plot, an observation area with a radius of 50 meters has been delimited for the collection of CSSV data (Fig. 4). In the case of this study, data were collected only on four plots at Petit-Bondoukou site.

\section{$10 \mathrm{~km}$}

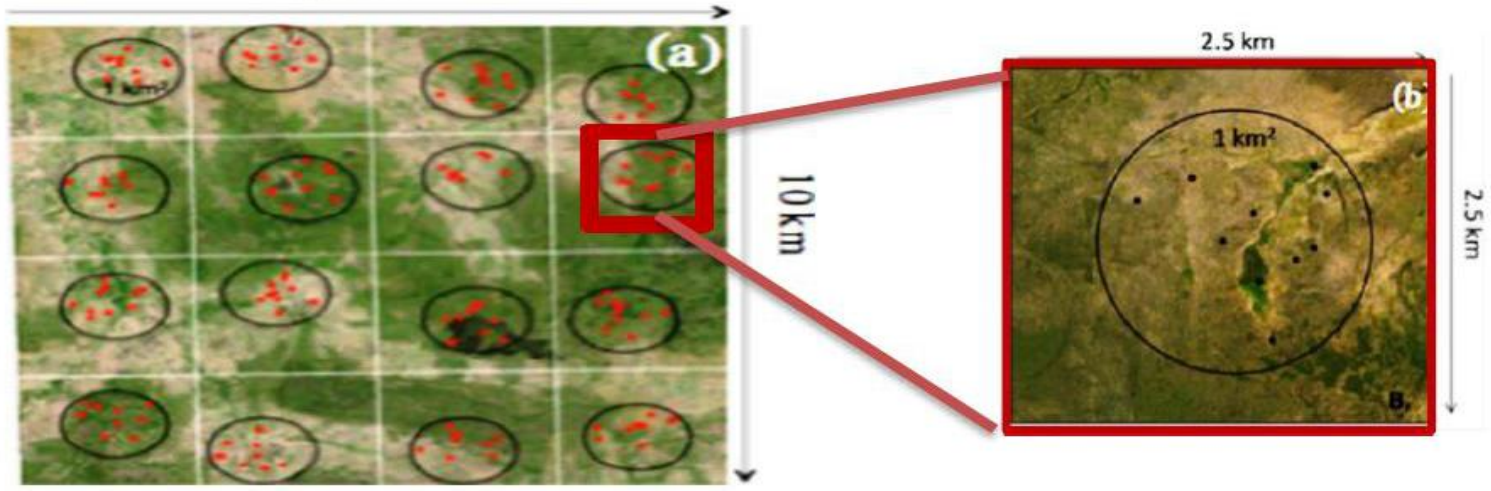

Fig. 3: Land Degradation Surveillance Framework (LDSF) (Diby et al., 2014) 


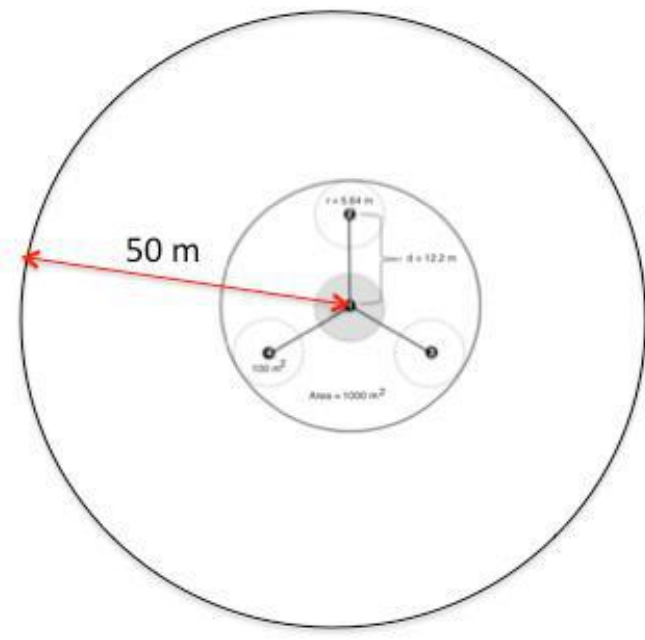

Fig.4: Observation areas and data collection for the CSSV (Diby et al., 2014).

\subsection{Data collection}

The data collected includes data on CSSV and farming practice data including plot maintenance and the level of cocoa leaf cover.

\subsubsection{CSSV data}

The CSSV data collection was carried out at each observation plot, previously identified using the Garmin 64s GPS. A $50 \mathrm{~m}$ radius observation area was delimited around the plot. Within this observation area, ten cocoa trees were selected as test trees. The status of the trees was determined from several indicators including symptoms on the leaves (redness on the leaf, mosaic on leaves), symptoms on stems (swellings) and symptoms on the pods (stunting). On the basis of these symptoms, the tree status is marked "presence" or "absence". The number of healthy or diseased cocoa trees was counted in the observation area and then the geographical coordinates of these trees were recorded. Then, a previously prepared survey sheet is filled in to constitute physical data.

\subsubsection{Farming practice data}

Farming practice data are related to the maintenance level of the plot and the leaf cover level of the test trees. The maintenance level is a qualitative data which is characterized by weeding of the plot and draining of the cocoa trees. There are two types of data: either the plot is maintained or not maintained. The leaf cover level is a qualitative variable with three modalities: the low cover level, the medium cover level and the high cover level. The low cover level is characterized by a tree that has a weak appearance and little shade. Low-cover trees are less productive and tend to lose their leaves throughout the season. On the other hand, the high cover level is represented by trees with strong shade and a crown cover. These trees are also apparently healthy and very productive.
In between the low and high cover level are the trees with medium cover level.

\subsubsection{Determination of the prevalence of Swollen shoot}

The prevalence of swollen shoot disease (P CSSD) is the ratio of the number of diseased cocoa trees counted to the total number of cocoa trees sampled in the observation area. This prevalence is represented by the following equation (1):

P CSSD $(\%)=\frac{\text { Number of diseased trees sampled }}{\text { Total number of trees sampled from plot }} \times 100$

\subsubsection{Statistical analysis}

The statistical analysis first consisted in describing the data on quantitative variables (prevalence of swollen shoot) and qualitative variables (CSSV status, Maintenance level and Leaf cover level) measured in the field. Then, the comparative analysis assessed the relationship between the prevalence of swollen shoot and the qualitative variables (maintenance level and leaf cover level). The ANOVA-oneway test was used to compare the averages of the prevalence of swollen shoot in the different categories of the qualitative variables. The non-parametric alternative of the one-way ANOVA (Kruskal-Wallis) test was preferred when the conditions for its application were not known. Thus, in order to study the influence of the leaf cover level on the prevalence of swollen shoot, the one-way analysis of variance was applied. The Kruskal-Wallis test was used to study the influence of maintenance level on the prevalence of swollen shoot. These statistical tests were all performed with IBM SPSS Statistic 20.0 software. 


\section{RESULTS}

3.1 Description of the prevalence, leaf cover level and maintenance level of cocoa plots

The result of the descriptive analysis (Table 1) shows that the average prevalence of swollen shoot at Petit Bondoukou site is $50 \%$ with a standard deviation of $36 \%$. This shows that the prevalence values are clustered around the average. In addition, $53 \%$ of the test trees were affected by swollen shoot disease compared to $48 \%$ of healthy test trees (Table
2). The description of the data on the leaf cover level showed that cocoa trees with high leaf cover are more dominant $(63 \%)$ than cocoa trees with medium (25\%) and low (13\%) leaf cover (Table 3). The cocoa trees on the site therefore have good leaf cover.

The description of the maintenance level of the plots showed that most of the observed plots are maintained at a rate of $63 \%$ compared to $38 \%$ for plots that are not maintained (Table 4).

Table 1: Result of the descriptive analysis of the prevalence of swollen shoot

\begin{tabular}{lccccc}
\hline & N & Minimum & Maximum & Average & $\begin{array}{c}\text { Standard } \\
\text { Deviation }\end{array}$ \\
\hline $\begin{array}{l}\text { Prevalence } \\
\text { CSSV (\%) }\end{array}$ & 40 & 00 & 100 & 50 & 35,81 \\
\hline
\end{tabular}

Table 2: CSSV status of sampled trees

\begin{tabular}{ccc}
\hline Status of trees & Number & Percentage \\
\hline Diseased & 21 & 52,5 \\
Healthy & 19 & 47,5 \\
Total & 40 & 100 \\
\hline
\end{tabular}

Table 3: Leaf cover level and CSSV Prevalence of test trees

\begin{tabular}{cccc}
\hline Leaf cover level & Number & Percentage & $\begin{array}{c}\text { CSSV Prevalence } \\
(\%)\end{array}$ \\
\hline Low & 5 & 12,5 & 80 \\
Medium & 10 & 25 & 70 \\
High & 25 & 62,5 & 36 \\
Total & 40 & 100 & $\mathbf{P}=\mathbf{0 , 0 0 3} *<\mathbf{0 , 0 5}$ \\
\hline
\end{tabular}

Table 4: Maintenance Level and CSSV prevalence of test trees

\begin{tabular}{cccc}
\hline Maintenance Level & Number & Percentage & CSSV Prevalence (\%) \\
\hline Not maintained & 15 & 37,5 & 50 \\
Maintained & 25 & 62,5 & 50 \\
Total & 40 & 100 & $\mathbf{P = 1 , 0 0 0 > 0 , 0 5}$ \\
\hline
\end{tabular}

3.2 Influence of the leaf cover level on the prevalence of swollen shoot

The result of the analysis of variance shows that there is a significant difference $(p=0.003<0.05)$ between the leaf cover level and the prevalence of CSSV (Table 3). According to Scheffe's test (Table 5), this significant relationship between the leaf cover level and prevalence of CSSV is due to the high level of leaf cover of cocoa trees which has the lowest prevalence of swollen shoot. 
Table 5: Scheffe test result for multiple comparison of means

\begin{tabular}{|c|c|c|c|c|c|c|c|}
\hline \multirow{2}{*}{\multicolumn{2}{|c|}{ (I) Cover leaf leve }} & & \multirow[b]{2}{*}{$\begin{array}{c}\text { Mean } \\
\text { differences (I-J) }\end{array}$} & \multirow[b]{2}{*}{$\begin{array}{l}\text { Standard } \\
\text { error }\end{array}$} & \multirow[b]{2}{*}{ Signification } & \multicolumn{2}{|c|}{$\begin{array}{c}\text { Confidence Interval } \\
95 \%\end{array}$} \\
\hline & & & & & & $\begin{array}{l}\text { Upper } \\
\text { Bound }\end{array}$ & $\begin{array}{l}\text { Lower } \\
\text { Bound }\end{array}$ \\
\hline \multirow{6}{*}{$\begin{array}{l}\text { Scheffe } \\
\text { Test }\end{array}$} & Low & Medium & 10,000 & 17,227 & ,831 & $-32,06$ & $\overline{52,06}$ \\
\hline & & High & $44,000^{*}$ & 15,408 & ,019 & 6,38 & 81,62 \\
\hline & Medium & Low & $-10,000$ & 17,227 & ,831 & $-52,06$ & 32,06 \\
\hline & & High & $34,000^{*}$ & 11,768 & ,017 & 5,27 & 62,73 \\
\hline & High & Low & $-44,000^{*}$ & 15,408 & ,019 & $-81,62$ & $-6,38$ \\
\hline & & Medium & $-34,000^{*}$ & 11,768 &, 017 & $-62,73$ & $-5,27$ \\
\hline
\end{tabular}

3.3 Influence of the maintenance level on the prevalence of the CSSV

The Kruskal-Wallis test showed that there is no significant difference $(\mathrm{p}=1.000>0.05)$ between the prevalence of CSSV and the maintenance level of the plots (Table 4). The prevalence of CSSV does not depend on the maintenance level of the plots.

\section{DISCUSSION}

\subsection{Description of the prevalence}

The results of swollen shoot disease's distribution showed that the Petit-Bondoukou site had a CSSV prevalence of $50 \%$. This results is in agreement with that obtained by Diby and his collaborators in 2014 which stipulated that PetitBondoukou site was one of the sites which is affected by swollen shoot disease. This confirms that the disease is progressing in the cocoa plantations of Soubré (Oro et al., 2012). Indeed, methods of uprooting infected trees are difficult for producers to adopt because they destroy larges areas of cocoa trees (Assiri et al., 2012; Kouakou et al., 2011).

4.2 Influence of the leaf cover level on the prevalence of swollen shoot disease

The result of the comparative analysis between the leaf cover level and the prevalence of swollen shoot showed that the prevalence of the disease depends on the leaf cover level of cocoa trees. Indeed, the prevalence of CSSV is higher in the presence of trees with low and medium leaf cover. This result is contrary to the studies conducted by Oro et al (2019) which stipulate that the high level of leaf cover influences the development of black pod disease of cocoa trees. The swollen shoot disease has a progressive and irreversible defoliation of the affected tree until its death (Oro et al., 2012). Indeed, swollen shoot disease is more felt in affected cocoa trees that have low leaf cover due to low photosynthetic activity. This low photosynthetic activity makes diseased cocoa trees less vigorous and exposes them more to the swollen shoot virus. This is reinforced by studies by Oro (2012) which indicated that the swollen shoot virus once in the plant, causes physiological and morphological disturbances in the affected cocoa tree. Thus, the virus causes root swelling followed by taproot abortion, as well as twig apexes and inhibition of terminal meristem function (Oro et al., 2012). This physiological dysfunction is followed by a slow down in tree growth which leads to complete defoliation of the diseased tree, thus creating outbreak of infection (CNRA, 2011; Kouakou et al., 2011).

4.3 Influence of maintenance level on the prevalence of swollen shoot.

The result of the Kruskal-Wallis test showed that the maintenance level of the plots has no influence on the prevalence of swollen shoot disease. However, according to Koigny (2015), unmaintained plots significantly cause the rapid progression of swollen shoot disease. This result could be explained by the low number of plots sampled (4 plots) in this study as opposed to the study by Koigny (2015) which was carried out in more than 100 plots. This low number of sampled plots would not allow us to perceive the influence of the maintenance level on the prevalence of the swollen shoot disease. In reality, when plots are not maintained on a regular basis the risk of spreading the disease is higher. Consequently, some weeds are reservoirs for a significant number of insect pests, including scale insects that carry swollen shoot disease, which can be potential sources of infection for healthy plants (CNRA, 2011; N'guessan et al., 2019). 


\section{CONCLUSION}

At the end of this study, it appears that Petit-Bondoukou site is a sentinel site of strong presence of the swollen shoot disease. The results of the statistical analysis showed that epidemiological factors such as the leaf cover level explain the development of swollen shoot disease in the plots. Cocoa trees with high leaf cover have low prevalence values of CSSV and cocoa trees with low and medium leaf cover have high prevalence values of CSSV. In contrast, the prevalence of swollen shoot disease does not depend on the maintenance level of the plots. These results obtained make it possible to make several recommendations to cocoa farmers. Regular weeding should be done to eliminate the sources of the swollen shoot virus vector. Similarly, regular pruning of cocoa trees should be carried out to allow good aeration of the plot, thus breaking the conditions for the development of scale insects that are vectors of swollen shoot disease.

\section{REFERENCES}

[1] Alibert H., 1946. Note préliminaire sur une nouvelle maladie du cacaoyer le «Swollen shoot». Agronomie Tropicale, Paris, V.1, pp. $34-43$.

[2] Assiri A, Kacou E, Assi FA, Ekra SK, Dji FK, Couloud JY et al. 2012. Rentabilité économique des techniques de réhabilitation et de replantation des vieux vergers de cacaoyers (Theobroma cacao L.) en Côte d'Ivoire. Journal of Animal \& Plant Sciences. 2012 ; 14 (2) : 1939-1951.

[3] CNRA, 2011. Centre National de Recherche Agronomique. Projet de lutte contre le swollen shoot en Côte d'Ivoire. Guide de la lutte contre la maladie du swollen shoot du cacaoyer en Côte d'Ivoire., 43 p.

[4] Diby L., Guillaume K., Marie-Paule N., Eric Y., Franck O., Ermias A., Emmanuel K., Christophe K., Richard C., Keith Shepherd., 2014. Cocoa Land Health Surveillance: An evidence-based approach to sustainable management of cocoa landscapes in the Nawa region, South-West Côte d'Ivoire. Working Paper 193. Abidjan, World Agroforestry Centre.

[5] Dzahini-Obiatey H., Owusu D. et Amoah F. M. 2010. Over seventy years of a viral disease of cocoa in Ghana: From researchers' perspective African Journal of Agricultural Research Vol. 5 (7), pp. 476-485.

[6] Freud E.H., Petithuguenin P. et Richard, J. 2000. Les champs de cacao : un défi de compétitivité Afrique Asie. Editions Karthala et CIRAD, Paris, 207 p.

[7] Hagen L.S., Jacquemond M., Lepingle A., Lot H., Tepfer M.1993. Nucleotide sequence and genomic organization of cocoa swollen shoot virus. Virology 196, 619-628.

[8] Kebe I., 2005. Cacaoyère ivoirienne en danger, le Swollen shoot progresse. Cnra, le point 2005.

[9] Kébé, B.I. et N'guessan, K. F., 2003. Rapport de la mission de prospection du Swollen shoot. 11 - 13 Septembre 2003. C.N.R.A - Divo, 7 p. N'Guettia A.M.C., 2015. Efficacité de doses de deux formulations de Movento (Ketoenoles) contre les cochenilles farineuses, vectrices du virus swollen shoot du cacaoyer dans la localité de Soubré (Sud-ouest de la Cote d'Ivoire). Mémoire de Master de l'Université Felix Houphouët Boigny, Abidjan, Côte d'Ivoire, 58 p.

[10] Koigny J. 2015. Impact des paramètres environnementaux sur la prévalence de la maladie du Swollen shoot du cacaoyer a Soubré au sud-ouest de la Côte d'ivoire. Mémoire de Licence en Production végétale de l'université Peleforo Gon Coulibaly de Korhogo, Côte d'Ivoire, 60 p.

[11] Koffié K, Kébé BI, Kouassi N, Aké S, Cilas C, Muller E.2012. Geographical of cocoa Swollen shoot virus molecularvariability in Côte d'Ivoire. Plant Disease. 96 (10) : 1445-1450

[12] Koua S. H., Coulibaly N. A. M-D., Alloueboraud W. A. M., 2018. Caractérisation vergers et des maladies de cacao de la Côte d'Ivoire : cas des départements d'Abengourou, Divo et Soubré. Journal of Animal \&Plant Sciences, 2018. Vol.35, Issue 3: 5706-5714.

[13] Kouakou K, Kebe BI, Kouassi N, Anno AP, Ake S, Muller E. 2011. Impact de la maladie virale du Swollen shoot du cacaoyer sur la production de cacao en milieu paysan à Bazré (Côte d'Ivoire).Journal of Applied Biosciences 2011 ; 43 : 2947-2957.

[14] Muller E, Sackey S. 2005.Molecular variability analysis of five new complete cacao swollen shoot virus genomic sequences Arch Virol. 2005; 150: 53-66.

[15] N'guessan WP, Yapi A, N'guessan KF, Kouamé NN, Gouaméné NC, Aka RA et al. 2019.Inventory and abundance of mealybugspecies in immature and mature cocoafarms in Côte d'Ivoire. Journal of AppliedEntomology. $2019 ; 143: 1065-1071$.

[16] N'Guettia A.M.C.2015. Efficacité de doses de deux formulations de Movento (Ketoenoles) contre les cochenilles farineuses, vectrices du virus swollen shoot du cacaoyer dans la localité de Soubré (Sud-ouest de la Cote d'Ivoire). Mémoire de Master de l'Université Felix Houphouët Boigny, Abidjan, Côte d'Ivoire, $58 \mathrm{p}$.

[17] Oro F. Z.2011. Analyse des dynamiques spatiales et épidémiologie moléculaire de la maladie du swollen shoot du cacaoyer au Togo : Etude de la diffusion à partir des systèmes d'information géographiques, Montpellier SupAgro. Thèse de Doctorat Ecole Doctorale SIBAGHE, 262p.

[18] Oro F. Z., Bonnot F., Ngo B. M. A., Delaitre E., Dufour B.P., Ametefe K. E., Mississo E., Wegbe K., Muller E., Cilas C. 2012. Spatiotemporal pattern analysis of Cocoa Swollen shoot virus in experimental plots in Togo. Plant Pathology, 61 (6): 1043-1051.

[19] Oro F. Z., Lallié H.-D., Doumbouya M., Koigny J. and Diallo H.A.(2019).Influence du niveau d'entretien des parcelles de cacaoyers sur la prévalence de la pourriture brune des cabosses à Kipiri, Sud-Ouest de la Côte d'Ivoire. Journal of Applied Biosciences 144 : 14813 - 14821.

[20] Partiot, M. Djiekpor, E K. Amefia, Y K. Bakar, K A. 1978. Le "swollen shoot" du cacaoyer au Togo. Inventaire préliminaire et première estimation des pertes causées par la maladie. Café, Cacao, Thé $22: 217-228$. 
International Journal of Environment, Agriculture and Biotechnology, 5(3)

May-Jun, 2020 / Available: https://ijeab.com/

[21] Serges T., 2014. Cote d'Ivoire: 1,74 million de tonnes de cacao récoltées en 2013-2014, record historique, Economie AFP, 6p.

[22] Tano M. A., 2012. Crise cacaoyère et stratégies des producteurs de la sous-préfecture de Meadji au Sud- Ouest Ivoirien. Thèse de doctorat de l'Université de Toulouse, France, 242p. 